\title{
Wegener's Granulomatosis Presenting with Pachymeningitis: Clinical and Imaging Remission by Rituximab
}

\author{
Søren Andreas Just, ${ }^{1}$ John Bonde Knudsen, ${ }^{2}$ Mie Kiszka Nielsen, ${ }^{3}$ and Peter Junker ${ }^{2}$ \\ ${ }^{1}$ Department of Internal Medicine, Odense University Hospital, Valdemarsgade 53, 5700 Svendborg, Denmark \\ ${ }^{2}$ Department of Rheumatology, Odense University Hospital, 5000 Odense, Denmark \\ ${ }^{3}$ Department of Radiology, Odense University Hospital, 5000 Odense, Denmark
}

Correspondence should be addressed to Søren Andreas Just, saj@dadlnet.dk

Received 23 March 2011; Accepted 12 April 2011

Academic Editors: J. K. Dawson, S. Morimoto, and A. Schattner

Copyright (C) 2011 Søren Andreas Just et al. This is an open access article distributed under the Creative Commons Attribution License, which permits unrestricted use, distribution, and reproduction in any medium, provided the original work is properly cited.

A 27-year-old woman was admitted for intractable right-sided neck, ear, and jaw pain with gradual development of tinnitus and hearing loss. A cerebral MRI showed meningo-dural enhancement, and additional diagnostic workup revealed a right pulmonary infiltrate and positive PR-3 ANCA. Biopsies from nasal mucosa and lung showed chronic inflammation with granuloma formation. Based on these findings the patient was diagnosed with Wegener's granulomatosis with pachymeningitis. There was no clinical response to oral Prednisolone and Cyclophosphamide, but complete clinical and imaging remission was achieved by adding Rituximab.

\section{Introduction}

Pachymeningitis is a rare feature of Wegener's granulomatosis (WG) and an uncommon initial manifestation of the disease [1]. We demonstrate that pachymeningeal lesions refractory to conventional therapy can resolve completely by the addition of Rituximab (RTX) to standard remedies. This case also illustrates that besides global headache, WGrelated pachymeningitis may occasionally manifest itself by lateralized pain and cranial nerve involvement [2-5].

\section{Case Report}

In 2004, a 27-year-old Caucasian female was admitted for persistent right-sided ear, jaw, and neck pain, with recent advent of tinnitus, hearing loss, and nasal sores. A CTscan showed mucosal thickening of the maxillary sinuses without bony erosions. A biopsy from nasal mucosa showed vasculitis and granuloma formation. Chest CT showed an apical infiltrate in the right lung and no mediastinal lymphadenopathy. A transthoracic lung biopsy revealed necrotic tissue and chronic inflammation with granuloma formation.
Bronchoalveolar lavage (BAL) fluid was negative for bacterial growth, mycobacterial PCR, and malignant cells. A PPD skin test was negative. However, the patient tested positive for PR3 ANCA $(49 \mathrm{U} / \mathrm{mL},<10)$. Blood cell counts were normal, CRP below $15 \mathrm{mg} / \mathrm{L}$, creatinine clearance, and urinalysis were normal. Based on these findings, the patient was diagnosed with Wegener's granulomatosis [6].

Cerebral magnetic resonance imaging (MRI) with gadolinium showed infratentorial, meningeal thickening along the right cerebellar tentorium, the cerebellopontine angle ascending into the right foramen jugulare. Besides, a thrombus extending from the right sinus transversus to bulbus venae jugularis was diagnosed. No nodular enhancement or infarcts were noted. Based on these findings, Wegener related pachymeningitis was suspected although not histologically confirmed.

Induction treatment included intravenous methylprednisolone pulses (1 gram/day for 3 days), plasma exchange on 5 consecutive days, and oral Cyclophosphamide.

Low molecular weight heparin and warfarin were added for prophylaxis against progression of cerebral venous thrombosis. 
TABLE 1: Clinical characteristics and outcomes in previous cases of Wegener's meningitis treated with Rituximab.

\begin{tabular}{|c|c|c|c|c|c|c|c|c|}
\hline Reference & Patient & $\begin{array}{l}\text { Previous } \\
\text { therapy }\end{array}$ & \multicolumn{2}{|c|}{ Treatment protocol } & $\begin{array}{l}\text { Followup } \\
(\mathrm{mo})\end{array}$ & $\begin{array}{l}\text { Time to } \\
\text { relapse } \\
(\mathrm{mo})\end{array}$ & $\begin{array}{l}\text { Rituximab } \\
\text { cycles }\end{array}$ & Outcome \\
\hline $\begin{array}{l}\text { Bawa et al. } \\
2007 \text { [7] }\end{array}$ & $\begin{array}{l}\text { Female } \\
36 \text { years }\end{array}$ & $\begin{array}{l}\text { CYC pulse } \\
\text { and GC } \\
\text { pulse }\end{array}$ & $\begin{array}{l}\text { First day: Rituximab } \\
\text { (1 g. iv.) } \\
\text { Methylprednisolone } \\
\text { ( } 250 \text { mg iv.) }\end{array}$ & $\begin{array}{l}\text { Second day: } \\
\text { Cyclophosphamide } \\
\text { ( } 750 \text { mg iv.)Regime } \\
\text { repeated once } 2 \text { weeks } \\
\text { later. }\end{array}$ & 6 & $\begin{array}{l}\text { No } \\
\text { relapse }\end{array}$ & 1 & $\begin{array}{l}\text { Complete clinical } \\
\text { remission, MRI } \\
\text { findings } \\
\text { persistent. }\end{array}$ \\
\hline $\begin{array}{l}\text { Tamura et } \\
\text { al. } 2007 \\
{[8]}\end{array}$ & $\begin{array}{l}\text { Female } \\
19 \text { years }\end{array}$ & $\begin{array}{l}\text { CYC pulse, } \\
\text { GC oral, } \\
\text { and MTX }\end{array}$ & $\begin{array}{l}\text { Rituximab } \\
\left(375 \mathrm{mg} / \mathrm{m}^{2}\right) \text { weekly } \\
\text { in four weeks }\end{array}$ & $\begin{array}{l}\text { Prednisolone } \\
100 \mathrm{mg} / \text { day gradually } \\
\text { tapered }\end{array}$ & 12 & 9 & 2 & BVAS $(19 \rightarrow 2)$ \\
\hline $\begin{array}{l}\text { Tamura et } \\
\text { al. } 2007 \\
{[8]}\end{array}$ & $\begin{array}{l}\text { Female } \\
35 \text { years }\end{array}$ & $\begin{array}{l}\text { CYC pulse, } \\
\text { GC oral } \\
\text { and pulse, } \\
\text { and } \\
\text { MTX/CSA }\end{array}$ & $\begin{array}{l}\text { Rituximab } \\
\left(375 \mathrm{mg} / \mathrm{m}^{2}\right) \text { weekly } \\
\text { in four weeks }\end{array}$ & $\begin{array}{l}\text { Prednisolone } \\
50 \mathrm{mg} / \text { day gradually } \\
\text { tapered }\end{array}$ & 5 & $\begin{array}{l}\text { No } \\
\text { relapse }\end{array}$ & 1 & BVAS $(13 \rightarrow 3)$ \\
\hline $\begin{array}{l}\text { Henes et } \\
\text { al. } 2007 \\
{[9]}\end{array}$ & $\begin{array}{l}\text { Male } \\
45 \text { years }\end{array}$ & $\begin{array}{l}\text { CYC oral } \\
\text { and pulse, } \\
\text { GC oral, } \\
\text { and INF }\end{array}$ & $\begin{array}{l}\text { Rituximab } \\
\left(375 \mathrm{mg} / \mathrm{m}^{2}\right) \text { weekly } \\
\text { in four weeks }\end{array}$ & $\begin{array}{l}\text { Prednisolone } \\
1 \mathrm{mg} / \mathrm{kg} / \text { day gradually } \\
\text { tapered. Leflunomide } \\
20 \mathrm{mg} / \text { day }\end{array}$ & 21 & 18 & 2 & $\begin{array}{l}\text { Some clinical and } \\
\text { MRI } \\
\text { improvement. }\end{array}$ \\
\hline $\begin{array}{l}\text { Sharma et } \\
\text { al } 2010 \\
{[10]}\end{array}$ & $\begin{array}{l}\text { Female } \\
22 \text { years }\end{array}$ & $\begin{array}{l}\text { GC oral } \\
\text { and pulse, } \\
\text { MTX, and } \\
\text { CYC pulse }\end{array}$ & $\begin{array}{l}\text { Rituximab } \\
\left(375 \mathrm{mg} / \mathrm{m}^{2}\right) \text { weekly } \\
\text { in four weeks }\end{array}$ & $\begin{array}{l}\text { Prednisolone } \\
60 \mathrm{mg} / \text { day gradually } \\
\text { tapered. }\end{array}$ & 6 & 6 & 2 & $\begin{array}{l}\text { Clinical remission } \\
\text { MRI not } \\
\text { described }\end{array}$ \\
\hline $\begin{array}{l}\text { Presented } \\
\text { case }\end{array}$ & $\begin{array}{l}\text { Female } \\
28 \text { years }\end{array}$ & $\begin{array}{l}\text { CYC oral } \\
\text { and pulse, } \\
\text { GC oral, } \\
\text { MTX, and } \\
\text { AZA }\end{array}$ & $\begin{array}{l}\text { Rituximab } \\
\left(375 \mathrm{mg} / \mathrm{m}^{2}\right) \text { weekly } \\
\text { in four weeks }\end{array}$ & $\begin{array}{l}\text { On separate day in } \\
\text { each week: } \\
\text { Methylprednisolone } \\
\text { ( } 250 \mathrm{mg} \text { iv.) } \\
\text { Cyclophosphamide } \\
\text { ( } 500 \mathrm{mg} / \mathrm{m}^{2} \text { iv.) }\end{array}$ & 30 & 9 & 4 & $\begin{array}{l}\text { Complete clinical } \\
\text { and MRI } \\
\text { remission }\end{array}$ \\
\hline
\end{tabular}

BVAS: Birmingham vasculitis activity score modified for WG, CYC: Cyclophosphamide, GC: Glucocorticosteroids, MTX: Methotrexate, CSA: Cyclosporine A, INF: Infliximab, AZA: Azathioprine. Iv.: intravenous.

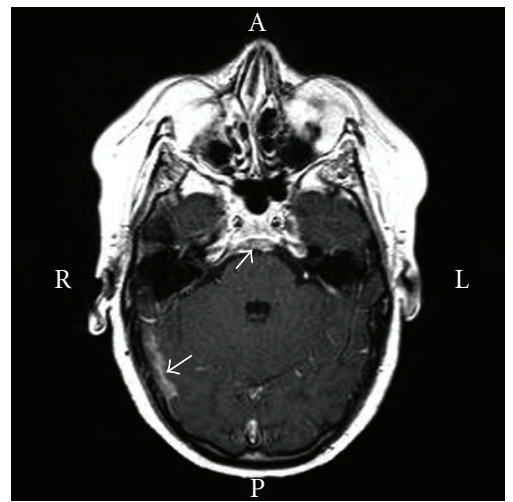

(a)

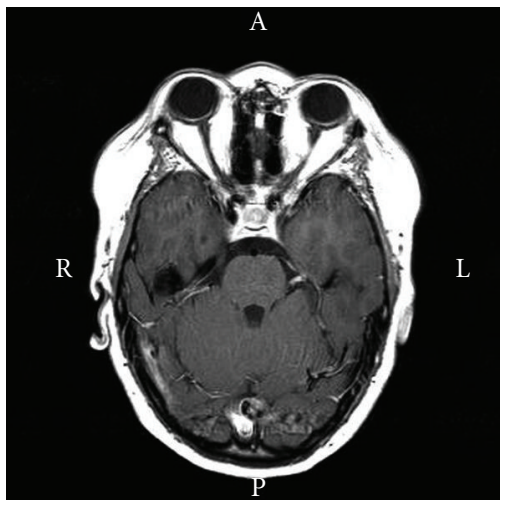

(b)

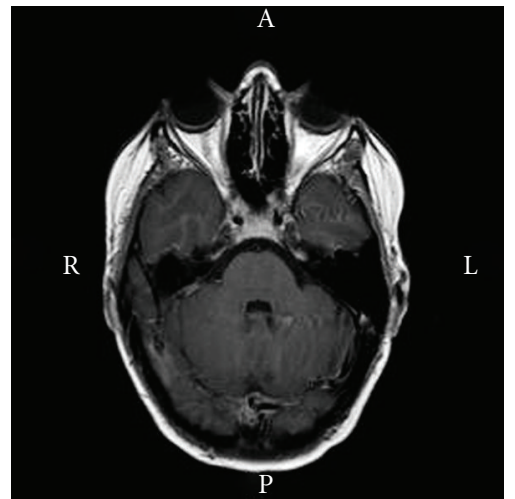

(c)

FIGURE 1: (a) T1W gadolinium-enhanced MRI 12.20.2006 showing meningeal thickening with enhancement on the dorsal and lateral aspects of the clivus close to the transverse sinus (arrows). (b) T1W gadolinium-enhanced MRI 06.08.2007. The meningeal thickening on the back of clivus has completely regressed, but the thickening on the right side near the transverse sinus remains visible. (c) T1W gadolinium-enhanced MRI 02.12.2009. Meningeal thickening and enhancement have resolved completely.

However, the Cyclophosphamide dosing target at $2 \mathrm{mg} / \mathrm{kg}$ could not be achieved due to debilitating nausea and liver toxicity, and she suffered from persistent cervicocranial pain despite normal CRP, PR-3 ANCA seroconversion, and partial regression of meningeal pathology by MRI.
In December 2006, the patient complained of diplopia. A repeat MRI scan showed marked progression of the infratentorial dura-meningeal enhancement (Figure 1(a)), whereas partial revascularisation of the transverse sinus was noted. Azathioprine $50 \mathrm{mg} /$ daily was added to the current Prednisolone medication (50 mg daily), but it had 


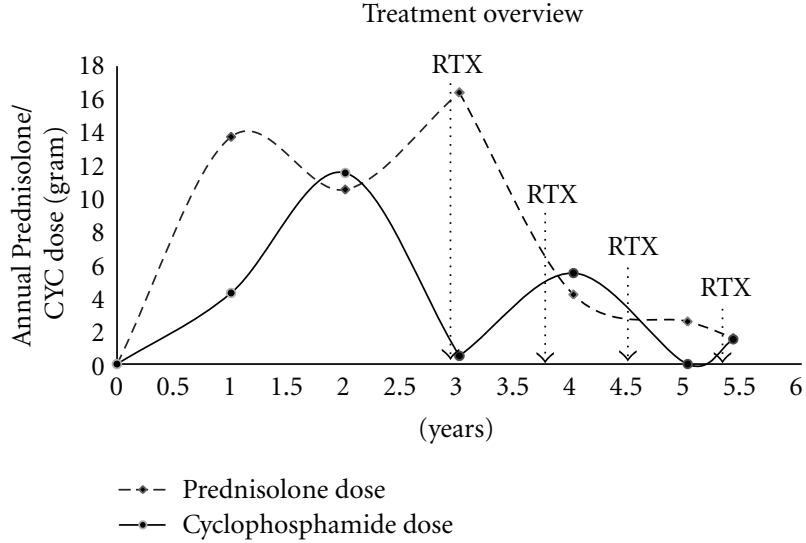

Figure 2: Cumulated annual Prednisolone and Cyclophosphamide (CYC) dose (gram). Rituximab (RTX) treatment cycles are indicated by arrows.

to be discontinued after 3 weeks due to intolerable nausea and elevated liver enzymes. Due to similar drug toxicity, Methotrexate $15 \mathrm{mg}$ weekly added to daily $40 \mathrm{mg}$ Prednisolone medication was abandoned after 2 months treatment. In February 2007, Rituximab was added as follows: 4 weekly Rituximab infusions $\left(375 \mathrm{mg} / \mathrm{m}^{2}\right)$ combined with i.v. Methylprednisolone ( $250 \mathrm{mg}$ ) and i.v. Cyclophosphamide $\left(500 \mathrm{mg} / \mathrm{m}^{2}\right)$ on a separate day. Already within 1 week after the first infusion, diplopia and neck pain had vanished. A follow-up MRI at 6 months showed partial regression of the meningeal pathology (Figure 1(b)), and chest CT revealed complete regression of the lung infiltrate. PR-3 ANCA remained negative. Cyclophosphamide was discontinued and Prednisolone gradually tapered to $5 \mathrm{mg}$ daily. Subsequently, relapsing neck and ear pain with concomitant epistaxis, nasal sores or sinusitis occurring at 8-10 months intervals have been successfully brought into remission 4 times using the treatment protocol described above. PR-3 ANCA has been undetectable throughout.

An MRI-scan in February 2009 showed complete regression of meningo-dural enhancement (Figure 1(c)).

\section{Discussion}

Global headache is the most frequent manifestation of WG related pachymeningitis although the condition may occasionally manifest itself with lateralized pain and cranial nerve involvement like in the present case [2-5].

Signs and symptoms of meningeal involvement in WG may result from different disease processes including vasculitis, bony destruction by invasive inflammatory cell infiltration or intraparenchymal granuloma formation $[3,5]$. Besides, the increased risk of complicating venous thromboembolism reported recently should be considered as illustrated by the sinus thrombosis encountered in this case [11].

The relative contribution of these pathways cannot be settled in this case, but the absence of destruction and granulomatous lesions by MRI favours a dominant role of vasculitis. Although conventional therapy using oral Prednisolone and Cyclophosphamide was followed by regression of the meningeal lesions seen on MRI, a parallel clinical response was not achieved. Probably, this is due to the submaximal dosing of these agents due to adverse effects.

Based on reports on favourable responses of RTX in refractory WG, we decided to add Rituximab to i.v. CYC and Glucocorticoid pulses. Although the exact mechanism behind the response to RTX in WG patients is unknown, it is likely that targeting CD20+ B-cells, which are precursors of ANCA-producing plasma cells, is important as evidenced by the long-term PR-3 ANCA seroconversion observed in this patient.

Successful treatment of Wegener's meningitis has been reported in the past (Table 1) [7-10]. This case is unique by demonstrating that multiple RTX cycles can be administered safely and effectively, resulting in long-term complete clinical and imaging remission despite substantially reduced immunosuppressive comedication, glucocorticoids in particular (Figure 2).

The effect of each single agent applied in the present combination protocol can not be determined. However, as shown in Figure 2, a marked reduction of the median PDN and CYC doses was observed during RTX treatment as compared with the pre-RTX period, thereby supporting the notion of a specific effect of RTX on WG disease pathways. This view is further supported by the need for repeat infusions (Figure 2).

In conclusion, this paper illustrates that WG may present with localized meningeal involvement and that Rituximab added to conventional agents has a steroid sparing effect and can lead to clinical and imaging remission in Wegener-related pachymeningitis.

\section{Conflict of Interests}

The authors declare that there is no conflict of interests.

\section{References}

[1] J. Dörr, S. Elitok, F. J. Dieste et al., "Treatment-resistant chronic headaches and focal pachymeningitis in a 46-year-old man: a rare presentation of Wegener's granulomatosis," The Lancet Neurology, vol. 7, no. 4, pp. 368-372, 2008.

[2] G. S. Hoffman, G. S. Kerr, R. Y. Leavitt et al., "Wegener granulomatosis: an analysis of 158 patients," Annals of Internal Medicine, vol. 116, no. 6, pp. 488-498, 1992.

[3] H. Nishino, F. A. Rubino, R. A. DeRemee, J. W. Swanson, and J. E. Parisi, "Neurological involvement in Wegener's granulomatosis: an analysis of 324 consecutive patients at the Mayo Clinic," Annals of Neurology, vol. 33, no. 1, pp. 4-9, 1993.

[4] J. M. Murphy, B. Gomez-Anson, J. H. Gillard et al., "Wegener granulomatosis: MR imaging findings in brain and meninges," Radiology, vol. 213, no. 3, pp. 794-799, 1999.

[5] G. Di Comite, E. P. Bozzolo, L. Praderio, M. Tresoldi, and M. G. Sabbadini, "Meningeal involvement in Wegener's granulomatosis is associated with localized disease," Clinical and Experimental Rheumatology, vol. 24, no. 2, pp. S60-S64, 2006.

[6] R. Y. Leavitt, A. S. Fauci, D. A. Bloch et al., "The American 
College of Rheumatology 1990 criteria for the classification of Wegener's granulomatosis," Arthritis and Rheumatism, vol. 33, no. 8, pp. 1101-1107, 1990.

[7] S. Bawa, C. Mukhtyar, S. Edmonds, and M. Webley, "Refractory Wegener's meningitis treated with rituximab," Journal of Rheumatology, vol. 34, no. 4, pp. 900-901, 2007.

[8] N. Tamura, R. Matsudaira, M. Hirashima et al., "Two cases of refractory Wegener's granulomatosis successfully treated with rituximab," Internal Medicine, vol. 46, no. 7, pp. 409-414, 2007.

[9] J. C. Henes, J. Fritz, S. Koch et al., "Rituximab for treatmentresistant extensive Wegener's granulomatosis_-additive effects of a maintenance treatment with leflunomide," Clinical Rheumatology, vol. 26, no. 10, pp. 1711-1715, 2007.

[10] A. Sharma, S. Kumar, A. Wanchu et al., "Successful treatment of hypertrophic pachymeningitis in refractory Wegener's granulomatosis with rituximab," Clinical Rheumatology, vol. 29, no. 1, pp. 107-110, 2010.

[11] Y. Allenbach, R. Seror, C. Pagnoux, L. Teixeira, P. Guilpain, and L. Guillevin, "High frequency of venous thromboembolic events in Churg-Strauss syndrome, Wegener's granulomatosis and microscopic polyangiitis but not polyarteritis nodosa: a systematic retrospective study on 1130 patients," Annals of the Rheumatic Diseases, vol. 68, no. 4, pp. 564-567, 2009. 


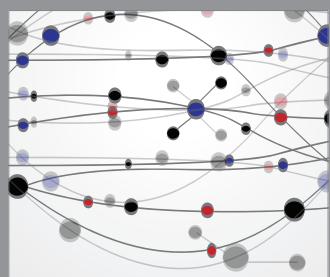

The Scientific World Journal
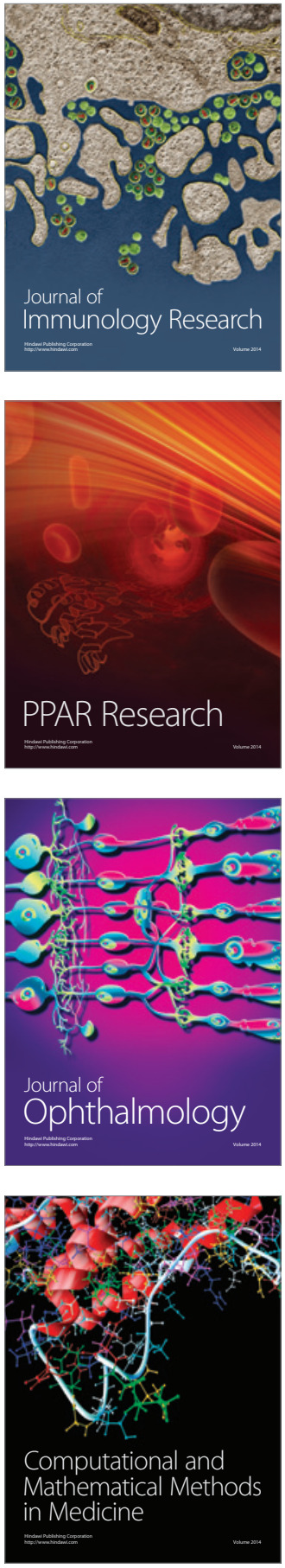

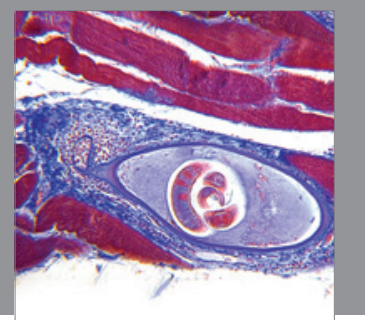

Gastroenterology

Research and Practice
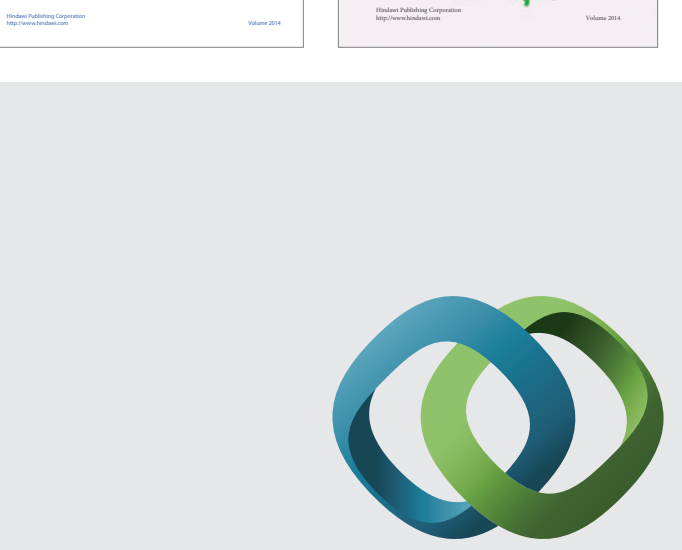

\section{Hindawi}

Submit your manuscripts at

http://www.hindawi.com
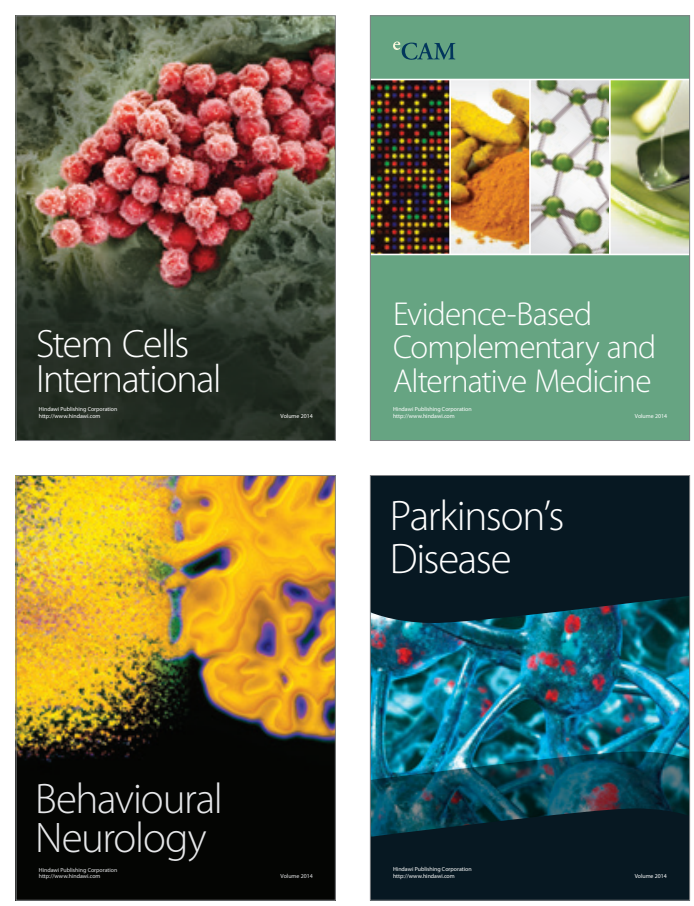

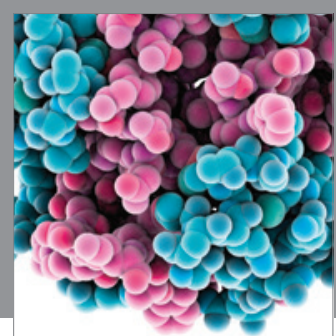

Journal of
Diabetes Research

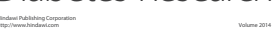

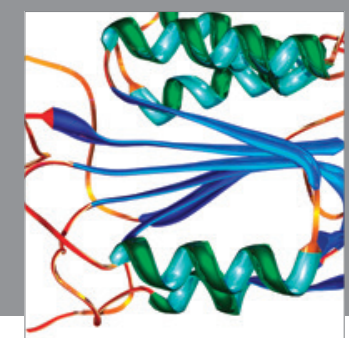

Disease Markers
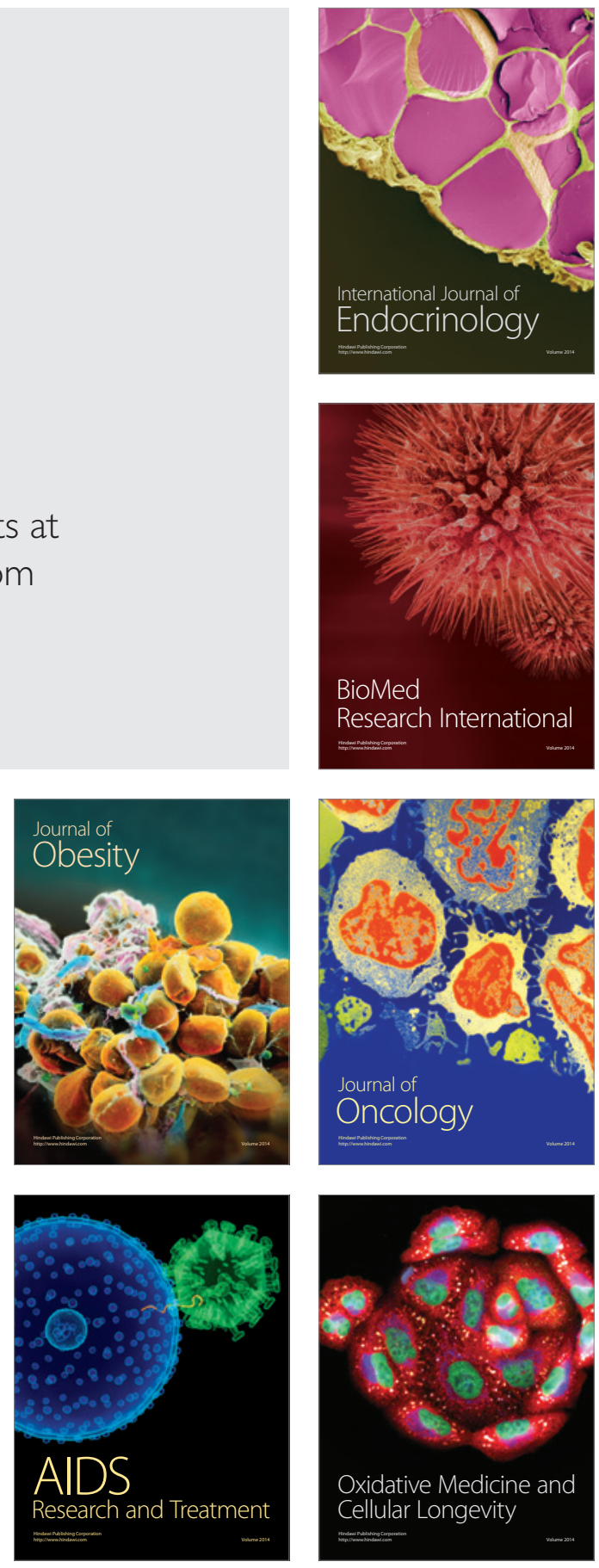